\title{
Settlements in Brazilian civil public actions: limits and possibilities of consensus after the 2015 Civil Procedure Code and the mediation act
}

\author{
Acordos em ações civis públicas no Brasil: limites e \\ possibilidades de consenso após o Código de Processo Civil \\ de 2015 e o ato de mediação
}

Humberto Dalla Bernardina de Pinho ${ }^{l}$

\begin{abstract}
:
The text seeks to demonstrate how Brazilian legislation has evolved along the way to allowing and making feasible settlements in collective issues. Moving away from a notion of an absolutely unavailable public right, Brazilian lawmaker has prioritized a consensual solution to disputes, even in the public and class sphere. This transition has been materialized, principally, by the undertaking of adjustment of conduct and public mediation. However, at this moment, it is important to set certain limits, so as not to lose sight of legal security and objective parameters to the settlements.
\end{abstract}

Key words: Consensus. Collective Protection. Limits. Possibilities.

\section{Resumo:}

O texto procura demonstrar como a legislação brasileira evoluiu ao longo do caminho para permitir e viabilizar acordos em questões coletivas. Afastando-se de uma noção de um direito público absolutamente indisponível, o legislador brasileiro priorizou uma solução consensual para as disputas, mesmo na esfera pública e de classe. Essa transição foi materializada, principalmente, pela realização de ajustes de conduta e mediação pública. No entanto, neste momento, é importante estabelecer certos limites, de modo a não perder de vista a segurança jurídica e os parâmetros objetivos dos acordos.

Palavras-chave: Consenso; Proteção coletiva; Limites; Possibilidades.

\footnotetext{
${ }^{1}$ Tenure Professor of Civil Procedural Law at Rio de Janeiro State University and Estacio University. Martin-Flynn Global Law Professor at University of Connecticut Law School. Rio de Janeiro StatePublic Prosecutor.
} 


\section{Initial remarks}

This study ${ }^{2}$ seeks to examine the institute of settlement, which has been undergoing major transformations in Brazilian law, starting with the advent of the Law of Mediation and the new practices linked to plea bargaining and leniency agreements, addressed, respectively, in Law Nos. 12.850/2013 and 12.846/2013.

In this regard, the principal goal of this work is to examine the objective limits of the settlement in situations that involve trans-individual rights protected by means of public civil actions.

In this context, focused on the protection of collective interests, ownership of which does not belong exclusively to those legitimized to file the public civil action, arises the undertaking of adjustment of conduct ("TAC"), as a relevant tool for conciliation, enabling access to consensual justice, while also suited to collaborating to freeing-up the judiciary machine by avoiding the filing of the competent class action.

One should note that this adjustment leads to various sensitive and current discussions: i) a wish to put into effect consensual collective protection, mitigating certain dogmas, such as that of the unavailability of public interests and trans-individual interests ${ }^{3}$;ii) applicability, or not, of all the solutions presented by self-settlement in the resolution of this complex kind of conflict, which are: settlement, court acknowledgement of the plaintiff's plea, abandonment of the lawsuit or the plea and waiving the claim of a material right; and iii)institution of efficient measures that prove to be in harmony with the greatest possible participation of all parties and stakeholders, so as to ensure the social control of decisions - or of structural decisions effected by means of structuring measures, plus ineluctable observance of the principle of publicity and administrative morality.

\footnotetext{
2 Paper presented in Jan 25th, 2018, at Uconn Law School Faculty Lounge, during my MartinFlynn Global Law Professor period. Many thanks to Professors Angel Oquendo and Peter Lindseth and to Dean Timothy Fisher, not only for the invitation, but, mainly for the opportunity of sharing these ideas and gaining so much profit by the rich debate initiated after the presentation.

${ }^{3}$ PINHO, Humberto Dalla Bernardina de; FARIAS, Bianca Oliveira de. Apontamentos sobre o compromisso de ajustamento de conduta na Lei de Improbidade Administrativa e no Projeto de Lei da Ação Civil Pública. In: Temas de Improbidade Administrativa. $1^{\text {st }}$ edition, Rio de Janeiro: Lumen Juris, 2010, v.1, p. 99.
} 


\section{The undertaking of adjustment of conduct as an initial form of} settling collective disputes

The legal nature of the undertaking of adjustment of conduct has been the target of wide-ranging debate, since its insertion into the $6^{\text {th }}$ paragraph of art. $5^{\circ}$ of the Law of the Public Civil Action, by the Consumer Defense Code. This is not a merely theoretical matter; on the contrary, it is important for measuring the objective scope of the settlement and, if negotiation is admitted within its realm, the possibility of identifying the products obtained from this practice ${ }^{4}$.

In any event, the "TAC" is always facultative in nature: that is to say, the public body cannot be obliged to offer it, and nor can the party investigated be forced to accept it on the terms proposed. There will always be a discretionary factor to be taken into account $^{5}$.

In general terms, two positionsamong authorsmay be identified: the first considers the adjustment as a "special settlement", while the second classifies it as a"bilateral legal deal, to some extent conciliatory, but not a settlement in its original sense" 7 .

However, we must note a recent and new guideline as to the negotiability of collective rights. Rigid positions end up being discarded, as they are based on generic arguments that have been harming the effectivity of the "TAC" on the practical level.

We therefore understand that it is no longer possible to uphold the omnipotent dogma on the absolute unavailability of the collective material right, ruling out a minimum of negotiating room necessary for putting the agreement into effect. Overcoming this line of thought, then, would seem to be indispensable to achieve the desires for a suitable collective system.

Still on the unavailability of this right, Angel Oquendo understands that this characteristic must be limited to its renunciation ${ }^{8}$. In addition, occasional questions or new facts can be discussed in future cases.

\footnotetext{
${ }^{4}$ CARVALHO FILHO, José dos Santos. Ação Civil Pública: Comentários por Artigo. $3^{\text {a }}$ Ed., Rio de Janeiro: Lumen Juris, 2001, p. 137.

${ }^{5}$ STJ (Higher Court of Justice) Special Appeal 596.764-MG, Reporting Justice Antonio Carlos Ferreira, judged on May $17^{\text {th }}, 2012$. Informativo STJ № 497.

${ }^{6}$ NERY, Ana Luiza de Andrade. Compromisso de Ajustamento de Conduta. Teoria e Análise de casos práticos. 2 ${ }^{a}$ Ed. São Paulo: Revista dos Tribunais, 2012, p. 119.

${ }^{7}$ RODRIGUES, Geisa de Assis. Ação Civil Pública e Termo de Ajustamento de Conduta: teoria e prática. 4.ed, Rio de Janeiro: Forense, 2013, p. 132.

8 " (...) a settlement may seem to boil down to condoning, for a fee or quick fix, the impingement upon the group right in question. It may appear to run counter to the characterization of such
} 
Therefore, experience demonstrates that a greater degree of autonomy for the public bodies to enter into the "TAC" would lead to greater efficacy, on the condition of observing certain parameters of control and limitation.

As well noted by Carlos Alberto de Salles ${ }^{9}$, the availability of the right is not related directly to its private or public nature.According to Bruno Takahashi ${ }^{10}$, on the basis of these premises, it is possible to find that the public interest, in itself, is not unavailable, but must be examined in the light of the peculiarities of the particular case.

As sustained by Ana Luiza Nery ${ }^{11}$ and Patrícia Miranda Pizzol ${ }^{12}$, the adjustment is a bilateral legal transaction that recognizes the purpose of contracting, modifying or extinguishing rights. The agreement would seek to achieve the best alternative for making good or avoiding harm to a meta-individual asset.

One cannot forget, as Angel Oquendo ${ }^{13}$ has already remarked, that a settlement is always a contract ${ }^{14}$ and a judicially approved settlement is considered a final judgment on the merits for the purposes of claim preclusion ${ }^{15}$.

So, starting from this idea, even though a rightful party may not relinquish a right essentially collective, there would be nothing to stop waiving, for instance, an accessory obligation, if this does not refer to the core of the central duty.

entitlements as inalienable or non-disposable, particularly in Latin America.Upon deeper inspection, however, this inalienability or non-disposability must merely mean that one may not renounce the right at issue or consent to an infringement. The government or any other nominal claimant may only seek vindication, whether by litigating or settling for adequate satisfaction equivalent to the expected adjudicative relief discounted by the costs and risks of litigation. (...) a suitable settlement neither undercuts nor undermines societal entitlements. Instead, it vindicates them. In this scenario, representatives require less time and expense to move the violator to restitute or compensate upon an impingement. Consequently, they may yield some on the total value of the anticipated adjudicative recovery and still come out ahead". OQUENDO, Angel. State Settlements in Vindication of Societal Rights. Original paper kindly provided by the author in January 2018, p. 29/31.

9 SALLES, Carlos Alberto de. Arbitragem em Contratos Administrativos. Rio de Janeiro: Forense, 2012, p. 294.

10 TAKAHASHI, Bruno. Desequilíbrio de poder e conciliação, Brasília: Gazeta Jurídica, 2016, p. 61.

${ }^{11}$ NERY JR., Nelson. O compromisso de ajustamento de conduta como transação hibrida e a problemática teorização da passagem do exercício do poder público para tentativa de ajuste no âmbito privado. In: A Ação Civil Pública após 25 anos. MILARÉ, Édis (coord.), São Paulo: Revista dos Tribunais, 2010, p. 160.

12 PIZZOL, Patrícia Miranda. Liquidação nas ações coletivas. São Paulo: Lejus, 1998, p.151.

${ }^{13}$ OQUENDO, Angel. State Settlements in Vindication of Societal Rights. Original paper kindly provided by the author in January 2018, p. 22.

${ }^{14}$ Knudsen v. Comm'r, 793 F.3d 1030, 1035 (9th Cir. 2015).

15 Toscano v. Conn. Gen. Life Ins. Co., 288 Fed. Appx. 36, 38 (3rd Cir. 2008). 
It is true that analysis of the feasibility of the negotiating, provided the collective material right is not relinquished in its substance, calls for a keen sensitivity ${ }^{16}$ from the legitimate public body ${ }^{17}$.

So, there must be a real verification of the principle of proportionality at all its levels of identification - need, suitability and proportionality strictly speaking - so as to choose the route most suited to put into effect, in the best possible way, the right violated, with the immediate reparation of the wrongful conduct ${ }^{18}$.

Determining the limits observed in the negotiation that addresses collective rights consists of another challenge to be faced, especially based on the changes announced, as we shall see further on.

As to the prohibitions on the content of the adjustment, certain clauses are proscribed ${ }^{19}$ : i) impossibility of preventing those harmed from access to the Courts, given the ineluctability of jurisdiction, set forth in art. 5, sub-item XXXV, of the Federal Constitution $^{20}$; and (ii) prohibition on weakening the core of the material right at stake. However, a settlement is not prohibited as to waiving a peripheral obligation or negligible part of the principal obligation.

Another point that warrants attention is the exceptional regime of administrative malfeasance (Law No. 8.429/1992). Art 17, $1^{\text {st }}$ paragraph, of this legislation, if

${ }^{16}$ STF. Extraordinary Appeal No. 253-885-0/MG, Reporting Justice Ellen Gracie. Published in the Court Gazette of June $21^{\text {st }}, 2002$.

17 STJ. Special Appeal No. 299.400/RJ, $2^{\text {nd }}$ Bench. Reporting Justice Eliana Calmon. Court Gazette of Aug. 2nd, 2006.

18 "In determining the fairness, reasonableness, and adequacy of a settlement, the court considers the substantive terms of the settlement compared to the likely result of a trial, as well as the negotiating process itself, examined in light of the experience of counsel, the vigor with which the case was prosecuted, and any coercion or collusion that may have marred the negotiations themselves A court determining whether a proposed settlement of a class action should be approved considers (1) the complexity, expense, and likely duration of the litigation, (2) the probability of the plaintiffs' success on the merits, (3) the stage of the proceedings and the amount of discovery completed, (4) the range of possible recovery, (5) the existence of fraud or collusion behind the settlement, and (6) the experience and opinions of class counsel and class representatives, (7) the substance and amount of opposition to the settlement, (8) the strength of plaintiff's case, (9) the risk of maintaining class action status throughout the trial, (10) the amount offered in settlement, and (11) the presence of a governmental participant". Thomas Smithand Elizabeth Williams. Court approval of class action settlement, 6 Cyc. of Federal Proc. $\S 23: 42$ (3d ed.). Access through Westlaw in Jan $5^{\text {th }}, 2018$.

${ }_{19}$ PINHO, Humberto Dalla Bernardina de. FARIAS, Bianca Oliveira de. Apontamentos sobre o compromisso de ajustamento de conduta na Lei de Improbidade Administrativa e no Projeto de Lei da Ação Civil Pública. In: Temas de Improbidade Administrativa.1a Ed, Rio de Janeiro: Lumen Juris, 2010, v.1, p. 116.

${ }^{20}$ In other words, another party enjoying co-legitimacy cannot be prevented from reaching a new undertaking with a broader scope, or with another obligation not included in the first agreement, or even from filing a public civil action when respectively fit. 
construed in isolation, forbids settlement, agreement or conciliation in actions destined to investigating the practice of an act of malfeasance committed by any public agent.

From another standpoint, it should be noted that the Law of Mediation, in art. $36,4^{\text {th }}$ paragraph, opens up the possibility of "in cases in which the subject of the dispute is being discussed in an action of administrative malfeasance, or if it is associated to a decision from the Federal Court of Accounts, the conciliation addressed in the main section will require the express consent of the judge (...)", which seems to throw new light on the discussion.

At first sight, the malfeasance law seems to present an absolute obstacle to completing a TAC, regardless of the legal nature defined for the undertaking.

The possibility of plea bargaining, addressed in Law No. 12.850/2013, brings new paradigms into the discussion ${ }^{21}$. The provision, of a clearly contractual nature ${ }^{22}$, favors co-plaintiffs, beneficiaries or accomplices who spontaneously reveal to the authorities the name of the mentors and principal authors of the fact.

Moreover, following the advent of Law No. 12.846/2013 - the Anticorruption Law, the permission to sign leniency agreements (arts. 16 and 17), seems to point more clearly towards the possibility of making more flexible the prohibition stated in art. 17 , $1^{\text {st }}$ paragraph of Law n. 8.429/92 23 .

As we may see, even on such a sensitive issue, the authors ${ }^{24}$ tend be flexible on the concept of material unavailability of the right, which is in line with the remarks set out in this text ${ }^{25}$.

This trend, as a matter of fact, was expressly received by Resolution No. 179/2017 from the National Council of the Public Prosecutor's Office.

21 PINHO. Humberto Dalla Bernardina de. MELLO PORTO, José Roberto Sotero de. Colaboração premiada: um negócio jurídico processual? In Revista Magister de Direito Penal e Processual Penal, vol. 73, Ago/Set 2016, Magister: Porto Alegre, p. 32.

${ }^{22}$ DIDIER JR, Fredie. BOMFIM, Daniela. Colaboração premiada (Lei n. 12.850/2013): natureza jurídica e controle da validade por demanda autônoma - um diálogo com o Direito Processual Civil,

https://www.academia.edu/25608182/Colabora\%C3\%A7\%C3\%A3o premiada Lei n. 12.850 2013_natureza_jur\%C3\%ADdica_e_controle_da_validade_por_demanda_aut\%C3\%B4noma_u m_di\%C3\%A1logo_com_o_Direito_Processual_Civil, acesso em 10 de julho de 2016, p. 17.

${ }^{23}$ The law was regulated by Decree No. 6.420, of March 18 2015. Portuguese text available at: http://www.planalto.gov.br/ccivil_03/_Ato2015-2018/2015/Decreto/D8420.htm. Access on June 152016.

${ }^{24}$ MARTEL, Letícia de Campos Velho. Direitos fundamentais indisponíveis: limites e padrões do consentimento para a autolimitação do direito à vida. Tese de Doutorado. Uerj, 2010. Disponível em: http://works.bepress.com/leticia_martel/, p. 18.

${ }^{25}$ VENTURI, Elton. Transação de Direitos Indisponíveis? In Revista de Processo, vol. 251, São Paulo: Revista dos Tribunais, jan / 2016, pp. 391/426. 
In this regard, the main section of art. 1 of this Resolution states that the TAC is an "instrument of warranty of diffuse and collective rights and interests, homogeneous individual and other rights whose defense is entrusted to the Public Prosecutor's Office, with the nature of a legal transaction with the purpose of adapting the conduct to the legal and constitutional requirements, with the effectiveness of an out-of-court title to execution as from its completion".

The most relevant matter for our study may be found in the $2^{\text {nd }}$ paragraph: "The commitment to adaptation of conduct is fitting in the hypotheses that configure administrative malfeasance, without prejudice to reparation to the public coffers and application of one of some of the sanctions ${ }^{26}$ laid down in law, in accordance with the conduct or act practiced".

Furthermore, the $3^{\text {rd }}$ paragraph of this art. 1 establishes that entering into the agreement does not rule out, necessarily, possible administrative or criminal liability for the same fact.

This point is especially relevant, since it confers greater legal security on the agreement. Thus, the undertaking may exclude or include benefits in the criminal and administrative spheres. However, in this case, some measures of caution must be adopted, particularly so as to maintain isonomy among the benefits granted to various suspects, and also to preserve the principle of the natural prosecutor. As a matter of fact, the $\mathrm{STJ}^{27}$ had already taken this line, even prior to the normative innovation.

Lastly, the $4^{\text {th }}$ paragraph leaves it to the discretion of the body of the Public Prosecutor's Office to decide as to the need, suitability and opportunity of public hearings with the participation of those interested. On this specific point, it seems to us that the measure should always be necessary, and not merely optional.

It is absolutely fundamental to take a sounding of organized civil society and those directly harmed by the wrongdoing. Failure to hold at least one public hearing may result in the Public Prosecutor's Office being isolated and thus the generation of an agreement that does not serve the interests of society in the best way, or, worse, an

\footnotetext{
${ }^{26}$ It should not be forgotten that art. 12 of Law No. 8.429/1992 sets the following sanctions for acts of malfeasance, to be applied cumulatively or alternately: a) loss of goods or sums added illicitly to the estate; b) full compensation of the damage; c) loss of the public function; d) suspension of political rights, from eight to ten years; e) payment of a civil fine of up to three times the value of addition to the estate; $f$ ) prohibition on contracting with the Public Power or receiving benefits or tax incentives for a term of ten years.

${ }^{27}$ STJ. Habeas Corpus 187.043-RS, Reporting Justice Maria Tereza de Assis Moura, judged on March $22^{\text {nd }}$, 2011. Informative STJ $N^{\circ} 211$.
} 
agreement that reveals aspeedy and consensual solution, but does not produce an effective and lasting solution to the problem.

\section{The fitness of mediation involving class or public issues.}

Besides the provision for the TAC in the specific legislation and also in art. 174, III, of the CPC (Code of Civil Procedure) combined with art. 32, III, of the Law of Mediation, we must also note that an agreement may be reached by other private parties with legitimacy, that is to say, without the participation of the Public Prosecutor's Office, the Defender's Department or even Public Attorney's Department.

We are referring, here, to those with legitimacy to file a public civil action, but who cannot, at least in a literal interpretation, take the undertaking of adjustment of conduct. This is the case, for instance, of professional associations, confederations and not-for-profit civil societies.

It should be recalled that art. $3,2^{\text {nd }}$ paragraph, of Law No. 13.140/2015 allows consensus involving collective unavailable rights, provided the agreement is submitted for court ratification, with a prior consultation to the Public Prosecutor's Office.

In this regard, we also could extend the application of this provision to transindividual rights and identify a hypothesis for agreement in a public civil action brought by a professional association (during the mediation or conciliation hearing, for example), if the judge understands that the right is negotiable (art. $334,4^{\text {th }}$ paragraph, sub-item II, of the CPC).

In actual fact, this agreement could be reached even prior to the civil public action, in a procedure of prior and out-of-court mediation.

If the action is brought by internal public-law legal entities (Federal Union, States, Municipalities and Federal District), we must remember that art. 32 of the Law of Mediation allows, expressly, not only mediation (sub-item II), but also promoting the TAC (sub-item III). Moreover, the $3^{\text {rd }}$ paragraph of art. 32 states that if there is a consensus between the parties, the agreement will be drafted and will constitute an outof-court title to execution, especially in cases of negotiable unavailable rights.

\section{The possibility of settlements over a class action procedure}


In the 1973 CPC, the idea of the procedural legal transaction was controversial ${ }^{28}$. Doctrine $^{29}$ considered it fitting in some exceptional cases, whenever there was an express rule of authorization, and case law ${ }^{30}$ was taking the same line. However, the matter was already being debated since the 1980 's ${ }^{31}$.

Leonardo Greco $^{32}$ systematizes the covenants into three groups:(i) those that affect only the procedural rights of the parties, without interfering in the prerogatives of the body in judgment, thus demonstrating that they are fit to produce immediate effects; (ii) those that affect the powers of the judge, which is authorized by law in the case of conjugation of intentions of the parties, for which reason they likewise produce effects from the outset; and (iii) those in which the conjugation of will of the parties must be added to the agreement of the judge, who will make an analysis of suitability and opportunity for the agreement to start to produce effects, given the lack of legal authority to limit powers only by the conjugation of wills of the litigants.

Still according to the author ${ }^{33}$, procedural covenants must obey the following requirements: (a) the possibility of self-settlement concerning the material right itself placed in judgment or the impossibility of the covenant harming the unavailable material right or its protection; (b) must be entered into by parties fully capable; (c) respect for balance between the parties and for parity of arms, so that one of them, by virtue of acts of disposition, its own or of its adversary, does not benefit from his particular position of advantage in relation to the other as to the right of access to means of action and defense; and (d) preservation of observance of the fundamental guarantees and principles of the process and procedural public order.

At this point, we understand that two issues require clarification: i) the first concerns definition of the scope of the expression procedural public order. As well

\footnotetext{
28 MACÊDO, Lucas Buril de; PEIXOTO, Ravi de Medeiros. Negócio processual acerca da distribuição do ônus da prova. Revista de Processo, vol. 241/2015, p. 463-487, mar/2015.

${ }^{29}$ CUNHA, Leonardo Carneiro. Negócios Jurídicos Processuais no Direito Brasileiro. Disponível na internet. https://www.academia.edu/10270224. Acesso em 17 de abril de 2015, p. 14.

${ }^{30}$ STJ, Special Appeal No. 35.786 SP, $4^{\text {th }}$ Bench. RSTJ, vol. 79, p. 238.

${ }^{31}$ BARBOSA MOREIRA, José Carlos. Convenção das partes sobre matéria processual. In: Temas de Direito Processual. $3^{\text {a }}$ série. São Paulo: Saraiva, 1984, pp. 87-88.

${ }^{32}$ GRECO, Leonardo. O juiz pode ser sujeito de um negócio processual? Palestra proferida no Seminário "Negócios Processuais no Novo CPC" promovida pela Associação dos Advogados de São Paulo/SP - AASP, em 06 de março de 2015.

${ }^{33}$ GRECO, Leonardo. Instituições de Processo Civil - Introdução ao Direito Processual Civil. vol. 1, 5. Ed., Rio de Janeiro: Forense, 2015, pp.61-62.
} 
noted by Diogo Almeida ${ }^{34}$, the expression refers to irremovable public rights, which fall on the fundamental rights of the process. ii) the second refers to the possibility of reaching procedural covenants even when a right identified as unavailable is at stake ${ }^{35}$.

As a consequence of the above issues, it is important to recognize that with the advent of the 2015 CPC (arts. 165 and $334,4^{\text {th }}$ paragraph) and the Law of Mediation (art. 3, $2^{\text {nd }}$ paragraph, of Law No. 13.140/2015), there is no longer any doubt as to the possibility of settlement in unavailable rights.

We have sustained ${ }^{36}$ that, faced with the terms adopted by the lawmaker, allied to the idea of a new meaning for unavailability based on the principles of contemporaneity, the scope of an unavailable right that does not admit self-settlement must be reduced to the cases in which there is an express prohibition of the agreement, or when the provision violates a fundamental right of the citizen.

In this regard, it would seem to be possible to reach prior or incidental private covenants in any of the modalities of trans-individual rights: diffuse, collective and individual homogeneous ${ }^{37}$. These covenants, if inserted into the contract that regulates provision of the service, bind the parties contracting in the event of an individual lawsuit being filed. We understand that the covenant may appear, also, in the undertaking of adjustment of conduct, or even be inserted into a specific document prepared to this end.

Besides this objective requirement, art. 190 mentions one of a subjective nature, in requiring that the parties must be fully capable. The logic of the Law is intuitive: only those fully fit to practice the acts of civil life may decide on the fate of protecting their rights in the case.

This capacity, for covenants prepared inside the proceeding, is assessed in its triple aspect: capacity to be a party, capacity to be in court and capacity to plead.

If both requirements are met, procedural agreements may be reached addressing: a) burdens; b) powers; c) faculties; and d) duties of plaintiff and defendant.

\footnotetext{
${ }^{34}$ ALMEIDA, Diogo Assumpção Rezende de. Das Convenções Processuais no Processo Civil. Tese de Doutoramento. Universidade do Estado do Rio de Janeiro - UERJ, Rio de Janeiro, 2014, p. 99.

${ }^{35}$ VENTURI, Elton. Transação de Direitos Indisponíveis? In Revista de Processo, vol. 251, São Paulo: Revista dos Tribunais, jan / 2016, pp. 392/393.

${ }^{36}$ See our exposition on Procedural Covenants, held in the Auditorium of the Minas Gerais Public Prosecutor's Office in August 2015: http://humbertodalla.podomatic.com/entry/2015-0819T07_10_28-07_00, access on November15 $5^{\text {th }} 2015$.

${ }^{37}$ Law $\mathrm{n}^{\circ}$ 8.078/1990 (Consumers Protection Code). Article 81, sole paragraph, sections I, II and III, respectively.
} 
The agreement may be prior (reached before the case, for example, in a contractual clause) or incidental (when the procedural relationship has already begun). Besides that, article $357,2^{\text {nd }}$ paragraph, of the Civil Procedure Code, which addresses the decision on the formalities of right of action, also states that the parties may submit to the judge, for ratification, a consensual delimitation of the de facto and de iure issues.

And also, art. $373,3^{\text {rd }}$ paragraph, likewise of the CPC, states that a different distribution of the burden of proof may also take place through agreement between the parties, except when it falls on an unavailable right of the party or makes it excessively difficult for one party to exercise the right.

One can conclude that these are concrete expressions of the principle of cooperation, generically set out in art. 6 of the Civil Procedure Code, and clearly inspired in the Portuguese Civil Procedure Code (2013).

Returning to art. 190, its sole paragraph determines that the judge, ex officio or at the urging of the interested party, shall control the validity of covenants, especially with a view to preserving the constitutional principles ${ }^{38}$, observing the limits imposed by procedural public order.

On examining the covenant, the judge may ratify it or, exceptionally, refuse it, only in the following cases: a) configuration of nullity; b) abusive insertion into a contract of adhesion; c) when one of the parties is in a patent situation of vulnerability. For Fernanda Tartuce ${ }^{39}$, vulnerability means susceptibility.

It is necessary here to establish in what sense the term must be construed. We ourselves believe that vulnerability, here, is only procedural, and must be assessed by the judge given the peculiarities of the particular case. It is, therefore, different from the vulnerability of the consumer, which is considered as a legal premise, regardless of whether or not there is a suit.

\section{A comparative look at the institute of settlement of the class actions}

\section{of United States law}

Within a new Brazilian civil procedural context, the 2015 Civil Procedure Code and the Mediation Act, forcing the need for a new analysis of the scope of negotiating

\footnotetext{
${ }^{38}$ BEDAQUE, José Roberto dos Santos. Tutela cautelar e tutela antecipada: tutelas sumárias e de urgência (tentativa de sistematização). 4. ed. São Paulo: Malheiros, 2006, p. 168.

39 TARTUCE, Fernanda. Igualdade e Vulnerabilidade no Processo Civil. São Paulo: Método, 2012, p. 184.
} 
the undertaking of adjustment of conduct, traditionally limited to ancillary aspects of the obligation, the study of the institute of the Class Action Settlement, addressed in United States law, proves to be interesting, given the wide margin for negotiation that it $\operatorname{possesses}^{40}$.

First of all, it should be noted that the prevalent method in dispute resolution is one of the most significant points of distinction between the Roman-Germanic and Anglo-Saxon cultures. In Civil Law, at least in the original tradition, there is a predominantly litigious conception of the proceeding, whereas in the Common Law scenario, especially in the U.S.A., lawsuits are rarely submitted to trial, but are settled by agreements between the parties.

It is important to note that Brian Fitzpatrick ${ }^{41}$ gives us an idea of the enormous growth of class action settlements approved in US court, comparing his conclusions to a former study made by Theodore Eisenbert and Geoffrey Miller ${ }^{42}$.

The U.S. context matches the value that the country places on liberal ideology, in particular autonomy of will. Within this doctrine, the judge exercises no activity in the individual settlements; - the U.S. legal system lacks any concept of "unavailable rights" as we know it.

For example, Rule 41(a) 1 (FRCP) states that as from the moment when the parties are in full agreement, the case will not require court ratification to be closed ${ }^{43}$. Exceptionally, the lawmaker requires judicial approval for the settlement.

\footnotetext{
40 In a paper written in 1971, Richard Dole pointed a promising future for collective bargaining agreements. "The challenge of providing appropriate procedures for the resolution of representative actions is substantial and continuing. Further experience with enlightened settlement techniques should do much to meet that challenge". DOLE Jr., Richard F. The Settlement of Class Actions for Damages. 71 Colum. L. Rev. 971.

41 "I found 688 settlements approved by federal district courts during 2006 and 2007 using the methodology described above. This is almost the exact same number the Eisenberg-Miller study found over a sixteen-year period in both federal and state court. Indeed, the number of annual settlements identified in this study is several times the number of annual settlements that have been identified in any prior empirical study of class action settlements. Of the 688 settlements I found, 304 of these settlements were approved in 2006 and 384 were approved in 2007". Fitzpatrick, Brian T. An Empirical Study of Class Action Settlements and Their Fee Awards. 7 Journal of Empirical Legal Studies (forthcoming 2010). Electronic copy available at: http://ssrn.com/abstract=1442108, access in November 2017, p. 9.

${ }^{42}$ EISENBERT, Theodore. MILLER, Geoffrey P. Attorney Fees in Class Action Settlements: An Empirical Study. Journal of Empirical Legal Studies Volume 1, Issue 1, 27-78, March 2004. Electronic copy available at: htttp://scholarship.law.cornell.edu/facpub/356/, access in November 2017.

${ }^{43}$ Rule 41. Dismissal of Actions: (a) Voluntary Dismissal. (1) By the Plaintiff. (A) Without a Court Order. Subject to Rules 23(e), 23.1(c), 23.2, and 66 and any applicable federal statute, the plaintiff may dismiss an action without a court order by filing: (i) a notice of dismissal before the
} 
Thus, in the context of class actions ${ }^{44}$, for a collective settlement to be effective and bind the individuals who have not had their "day in court", the Judiciary Branch must deem it suited to the defense of all the interests of the members of the class.

And here it is necessary to emphasize that there is enormous controversy in US legal doctrine on the institute of the class action settlement. From the authors who sustain that the mechanism should not exist ${ }^{45}$, or even that it should receive more rigid rules. Even with the successive reforms implemented, both in the Rules and in the US Code, the courts are still facing stormy issues, involving: i)intra-class conflicts ${ }^{46}$, ii) disproportionate attorney`s fees ${ }^{47}$, iii) lack of legal parameters regarding the extension

opposing party serves either an answer or a motion for summary judgment; or (ii) a stipulation of dismissal signed by all parties who have appeared.

${ }^{44}$ FISS, O.M. Against Settlement, 93 Yale Law Journal 1073-90, May 1984, p. 1443.

45 "It is time to abandon the settlement class action. Notwithstanding the device's attractiveness to defendants, to plaintiffs' counsel, and to judges as a means of achieving comprehensive resolutions, it does not withstand scrutiny as a legitimate exercise of judicial authority. There is no sound basis on which a settlement class action, in the absence of litigation class certification, should bind class members. We need to be clear on what a settlement class action is, or more precisely, what it is not. It is not a contract, at least not in the sense of an agreement to which the class members are parties. It is not an adjudication on the merits. Rather, it is an act of judicial power premised on a negotiated resolution. But the underlying negotiation has the odd characteristic that the negotiator for the claimants is a prospective agent who has neither been authorized to act on behalf of the claimants nor been granted the power to take their claims to trial. This feature creates an asymmetrical dynamic that negates any argument that the act of judicial power is justified by a presumption of fair valuation of claims. The problem is not one of collusion or bad faith, but rather a structural problem built into the very definition of a settlement class action". ERICHSON, Howard M. The Problem of Settlement Class Action. 82 Geo. Wash. L. Rev. 951. Access through Westlaw in Jan 9' 2018.

${ }^{46}$ And there is also the stormy question of conflicts within the class and the consequent need to make the agreement fair and adequate for all. "But late twentieth century sensibilities regarding the nature of class conflicts that might threaten adequate representation, regarding the role of conflicts management in assuring adequate representation, and regarding sub-classing as the vehicle for achieving it, all now seem quaint and out of touch with current institutional arrangements. It's high time to recognize the collapse of the class conflicts management regime announced in Amchem and Ortiz and to acknowledge the contours of the new regime emerging in its stead". RATNER, Morris A. Class Conflicts, 92 Wash. L. Rev. 785. Access through Westlaw in Jan 6th 2018.

47 The proposed settlement presented in In re Electronic failed in two regards. The court caught the first with its Reed-factor analysis, finding the actual terms of the settlement to be "not in the best interests of the proposed class members." And while the court recognized the second--the discrepancy between the class's recovery and the attorneys' fees - a more thorough opinion would have employed a Johnson-factor analysis to better illuminate the court's misgivings and avoid the possibility of reversal. Though it can be argued that an otherwise acceptable settlement should be approved despite misgivings about fees, a settlement unacceptable in both terms and the amount of attorneys' fees should never be accepted. In the end, "Chevrolettype results do not warrant Cadillac-size legal fees."ALMON, Matthew. Cadillac-Size Legal Fees" and "Chevrolet-Type Results": Settlement Scrutiny in Re Electronic Data Systems Corp. "Erisa" Litigation, 80 Tul. L. Rev. 2007. Accesso through Westlaw. 22nd Jan 2018. 
of the agreement ${ }^{48}$ and also the discretion of the court to approve the agreement or not ${ }^{49}$, and iv) absence of effectiveness of the agreement for the injured parties ${ }^{50}$.

Thus, the system, on the one hand, makes express provision for the possibility of agreements between the parties in the three hypotheses ${ }^{51}$ of class actions contemplated by Rule 23 (B1 and B2 are considered mandatory class actions, and B3 admits the opt out mechanism), while at the same time imposing special requirements for their completion $^{52}$. Note that in the case of so-called "coupon settlements" there is still a specific rule in the US Code ${ }^{53}$.

48 "Specifically, we propose that for questions going to the adequacy of a settlement, where no warning signals of fraud or collusion are found, the court should act relatively deferentially by employing a lenient standard of scrutiny and approving a settlement if it has a rational basis. An intermediate level of scrutiny should apply when the settlement presents facial issues that implicate the fairness of the settlement. Such facial issues include the allocation of settlement proceeds among subgroups in a class, the presence of coupon-type relief, "shotgun" settlements occurring very early in the litigation, and settlements in overlapping class actions. In settlements with one or more of these characteristics, if the initial inquiry raises concerns, the court should demand a well-reasoned explanation for the choices made. Finally, where the components of a settlement present a direct conflict between the interests of class counsel and those of the class issues, such as issues related to attorneys' fees, courts should employ exacting scrutiny and require convincing evidence that the proposal is reasonable". Jonathan R. Macey. Geoffrey P. Miller. Judicial Review of Class Action Settlements, 1 J. Legal Analysis 167. Access through Westlaw in Jan $8^{\text {th }}, 2018$.

49 "The confusion and inconsistency in standards for review of class action settlements is due to a failure to recognize that different levels of scrutiny are suited to different questions. Courts should apply lenient scrutiny on questions going to the settlement's adequacy, requiring only plausible justifications for decisions made in the absence of indicia of fraud, collusion, or conflict of interest. Courts should apply intermediate scrutiny to concerns about fairness--allocation issues, coupon relief, shotgun settlements, and potential "reverse auction" settlements in overlapping cases-- and should insist on well-reasoned explanations for why these concerns are unfounded. Exacting scrutiny is required for counsel fees. Overall, Rule 23(e)' s requirement that a settlement be "reasonable" should be administered flexibly depending on the issue involved". MACEY, Jonathan R. MILLER, Geoffrey P. Judicial Review of Class Action Settlements, $1 \mathrm{~J}$. Legal Analysis 167. Access through Westlaw in Jan $16^{\text {th }}, 2018$.

50 "The class action settlement is a business deal, a contract, between skilled negotiators (...). Yet it too is a contract that cannot stand on its own feet. The class action settlement lacks stability not because the masses have so much at stake that they are well informed and impassioned, but rather because the masses have so little at stake that they are ignorant and indifferent. The problem is not that their agents have sold them out, but that they do not even know they have agents. In the face of this apathy, the task once again falls to a court to legitimate the deal--and what better way to do so than to hold a hearing and name it "fairness." (...) If the fairness hearing is to be anything more than dissimulation, the legal system must arm judges with tools that will enable them to do the job for real". RUBENSTEIN, William $B$. Emerging Issues in Class Action Law. 53 UCLA L. Rev. 1435. Access through Westlaw in Jan 18th, 2018.

51 Class actions which are certified on basis that prosecution of separate actions would create risk of inconsistent or varying adjudications, or impairment of ability of nonparties to protect their interests, do not provide for absent class members to receive notice and to exclude themselves from class membership as a matter of right, and for this reason are often referred to as "mandatory class actions." Fed. Rules Civ. Proc. Rule 23(b)(1), 28 U.S.C. A. Ortiz v. Fibreboard Corp., 527 U.S. 815 (1999).

52 This is a rule stated in sub-item (a) of Rule 23 of the Federal Rules of Civil Procedure: (e) Settlement, Voluntary Dismissal, or Compromise. The claims, issues, or defenses of a 
Firstly, there is a provision of a generic nature, namely, prior approval of its terms by the court ${ }^{54}$. On top of this, Rule 23 (e) establishes others in items (1) through (5), while that addressed in item (4) refers exclusively to the class actions certified under Rule (b) 3, and states that the court may refuse approval of a settlement, unless the members of the group are assured of a new opportunity to exercise their right to selfexclusion from the action ${ }^{55}$, which is not found in Brazilian law, and comes in for strong criticism in doctrine ${ }^{56}$.

There is, quite clearly, greater caution with the need to notify the members of a class in an action based on Rule 23 (b) 3, coherent with the individual aspect of the interests in dispute. In addition, it is essential that the self-appointed plaintiff has the same interests as the other members of the class $^{57}$.

certified class may be settled, voluntarily dismissed, or compromised only with the court's approval. The following procedures apply to a proposed settlement, voluntary dismissal, or compromise: (1) The court must direct notice in a reasonable manner to all class members who would be bound by the proposal. (2) If the proposal would bind class members, the court may approve it only after a hearing and on finding that it is fair, reasonable, and adequate. (3) The parties seeking approval must file a statement identifying any agreement made in connection with the proposal. (4) If the class action was previously certified under Rule 23(b)(3), the court may refuse to approve a settlement unless it affords a new opportunity to request exclusion to individual class members who had an earlier opportunity to request exclusion but did not do so. (5) Any class member may object to the proposal if it requires court approval under this subdivision (e); the objection may be withdrawn only with the court's approval.

${ }^{53} 28$ USC. § 1712. Coupon settlements. (...) (e) Judicial scrutiny of coupon settlements. In a proposed settlement under which class members would be awarded coupons, the court may approve the proposed settlement only after a hearing to determine whether, and making a written finding that, the settlement is fair, reasonable, and adequate for class members. The court, in its discretion, may also require that a proposed settlement agreement provide for the distribution of a portion of the value of unclaimed coupons to 1 or more charitable or governmental organizations, as agreed to by the parties. The distribution and redemption of any proceeds under this subsection shall not be used to calculate attorneys' fees under this section. https://www.law.cornell.edu/uscode/text/28/1712, access in January 17th, 2018.

54 In deciding whether to grant preliminary approval of proposed class action settlement, court determines whether proposed settlement discloses grounds to doubt its fairness or other obvious deficiencies such as unduly preferential treatment of class representatives or segments of class, or excessive compensation of attorneys, and whether it appears to fall within range of possible approval. Fed. Rules Civ. Proc. Rule 23(e), 28 U.S.C.A. In re National Football League Players' Concussion Injury Litigation, 301 F.R.D. 191 (2014).

55 "Reasonable settlement notice may require individual notice in the manner required by Rule 23(c)(2)(B) for certification notice to a Rule 23(b)(3) class. Individual notice is appropriate, for example, if class members are required to take action-such as filing claims-to participate in the judgment, or if the court orders a settlement opt-out opportunity under Rule 23(e)(3)." CommitteeNotes on Rules. 2003 Amendment. Available at: $<$ http://www.law.cornell.edu/rules/frcp/rule_23>. Access on Jun $18^{\text {th }} 2013$.

$56 \mathrm{GIDI}$, Antonio. A Class Action como instrumento de tutela coletiva de direitos.São Paulo: Revista dos Tribunais, 2007, p. 326

${ }^{57}$ In order to justify a departure from usual rule that litigation is conducted by and on behalf of individual named parties only, class representative must be part of class and possess same interest and suffer same injury as class members. Fed. Rules Civ. Proc. Rule 23, 28 U.S.C.A. Wal-Mart Stores, Inc. v. Dukes, 564 U.S. 338 (2011). 
Thus, the judge has the function of guaranteeing the rights of the members absent and the rights of the group, which might be violated if this provision did not exist ${ }^{58}$.Within this scenario, the claim, at the origin, will be individual, until the representative of the class requests the so-called Motion for Certification, a request whereby he seeks recognition, in the case, of the conditions set for handling a case collectively ${ }^{59}$.

There is also the possibility of negotiation taking place out of court. In this case, both parties file a motion for certification "as a class action for settlement purposes only", for the judge to assess that the party who replaced the class is suitably representative ${ }^{60}$.

In this case, the expression Settlement Class Action ${ }^{61}$ is used, differing from the Class Action Settlement in that there is already an agreement prior to filing the suit, which returns to confer efficacy erga omnes on the settlement already achieved, and it is not, thus, an agreement obtained after certification of the class action.

The submittal of settlements, at times disadvantageous or unfair, is interesting to the defendant to avoid the marginal damages caused by a lawsuit with great repercussion.The function of Certification, therefore, is that of affording a watershed between the individual action and that of sizeable dimensions with all its

58 PINHO, Humberto Dalla Bernardina de. The Undertaking of Adjustment Of Conduct In Brazilian Collective Procedural Law. Connecticut Journal of International Law. Vol, 27: 346, Spring 2012, p. 185.

${ }^{59} \mathrm{FISS}$, O.M. The Class Action Rule, 78 Notre Dame Law Review, 1419 (2003).

${ }^{60}$ Asbestos products manufacturers who were members of Center for Claims Resolution (CCR), and whose stipulation of proposed global settlement of claims by persons exposed to asbestos had been court-approved, moved to enjoin actions against them by individuals who failed to timely opt out of class. The United States District Court for the Eastern District of Pennsylvania, Lowell A. Reed, Jr., J., 878 F.Supp. 716, granted injunction under All-Writs Act and AntiInjunction Act. Parties objecting to class certification appealed, and the Court of Appeals for the Third Circuit, 83 F.3d 610, vacated and remanded with directions to decertify class. Certiorari was granted, and the Supreme Court, Justice Ginsburg, held that: (1) district court faced with request for settlement-only class certification need not inquire whether case would present intractable problems of trial management, but other requirements for certification must still be satisfied, abrogating In re Asbestos Litigation, 90 F.3d 963,White v. National Football League, 41 F.3d 402, In re A.H. Robins Co., 880 F.2d 709, and Malchman v. Davis, 761 F.2d 893, and (2) requirements for class certification of commonality of issues of fact and law and adequacy of representation were not met. Amchem Products, Inc. v. Windsor, 521 U.S. 591 (1997). Access through Westlaw in Jan $11^{\text {th }}, 2018$.

${ }^{61}$ ROQUE, Andre Vasconcelos. Class actions - ações coletivas nos Estados Unidos: o que podemos aprender com eles? Salvador: Juspodivm, 2013, p. 379. 
particularities $^{62}$, whose verification strengthens the bargaining power of the class in relation to the defendant.

Following certification, besides bolstering the legal position of the claimant, the respondent finds in the settlement an alternative for definitive binding in relation to all the members of the class.

Another aspect that contributes to the large number of settlements is the interest of the group's lawyer in seeing his investment returned right away, avoiding the risks of losses arising from a future and possible rejection. In the U.S. context, it is the lawyer who generally shoulders the costs necessary for handling the class action, seeking to earn a profit from an investment which, in theory, compensate the risks assumed.

At the moment of validating the collective settlement presented, on the basis of Rule 23 subdivision (e), the judge must appraise whether the agreement is fair, suitable and reasonable ${ }^{63}$. Even though they are indeterminate legal concepts, the Manual for Complex Litigation, similar to a compilation of case-law guidance to the Federal Courts, contains methodological guidelines for the correct application of these criteria following the 2004 reform $^{64}$.

Analysis of the fairness of the agreement is based on the proper treatment given by the negotiation to the absent class members. For example, there is a check whether there is an unjustified position of advantages between the members of the group who were or were not present in the class at the time of the negotiation. And sometimes, this control ends up being made by a superior court, even if the lower court has ratified the agreement ${ }^{65}$. Suitability and reasonability, in their turn, are assessed by weighing-up the

\footnotetext{
${ }^{62} \mathrm{FISS}, \mathrm{O}$.M. The political theory of the class action. Washington and Lee Law Review vol. 53 (1996), pp. 21/31.

63 In evaluating the fairness of a proposed class action settlement, court considers: (1) the strength of plaintiffs' case compared to the amount of defendants' settlement offer; (2) an assessment of the likely complexity, length, and expense of the litigation; (3) an evaluation of the amount of opposition to settlement among affected parties; (4) the opinion of competent counsel; and (5) the stage of the proceedings and the amount of discovery completed at the time of settlement. Fed. R. Civ. P. 23(e)(3). In re Capital One Telephone Consumer Protection Act Litigation, 80 F.Supp.3d 781 (2015).

${ }^{64}$ Available at: https://public.resource.org/scribd/8763868.pdf, p. 351. Accessed on Oct. 10 2015.

${ }^{65}$ On the other hand, some appellate courts have rejected settlements when the record reflects a lack of careful consideration by the district court. For instance, in Reynolds v. Beneficial National Bank, 288 F.3d 277 (7th Cir. 2002), the Seventh Circuit, in an opinion by Judge Posner, overturned a class settlement on the ground that the trial court should have made a greater effort (he made none) to quantify the net expected value of continued litigation to the class, since a settlement for less than that value would not be adequate. Determining that value would require estimating the range of possible outcomes and ascribing a probability to each
} 
advantages presented by the settlement and the likelihood of success in a class action, examination of which must be done casuistically.

So, bringing these ideas to Brazilian reality, the advent of art. 174, sub-item III, of the 2015 Code and arts. 3, $2^{\text {nd }}$ and 32, sub-item III, of Law No. 13.140/2015, as we have seen above, brought to light the possibility of negotiating the very basis of the collective right. Was there, then, inspiration from U.S. law in an aspect hitherto overlooked by Brazilian law ${ }^{66}$ ?

The most controversial point would appear to be the fact that, even though art. 32, sub-item III, took inspirations from the Settlement, it did not establish court certification as a premise for producing the effects of the collective stipulation, given that the TAC possesses, legally, the efficacy of an out-of-court title to execution.

The control of the Judiciary Branch, in the U.S.A., appears as a fundamental point for ensuring that the agreement is advantageous for those who did not participate directly in its formation, since the res judicata, on the terms agreed, will be produced erga omnes.

As this is a decision in principle immutable ${ }^{67}$, prior to the judicial seal of approval for the settlement, all those interested (absent members), must be intimated by means appropriate to the case, as provided for in Rule 23 (e). Moreover, ratification is always done in a public hearing (Fairness Hearing), preceded by discussions, the presentation of objections and arguments on the fairness, suitability and effectiveness of the agreement.

The sophisticated system of casuistic control of the suitability of the representative of the group chosen in court (Ideological Plaintiff), ensures his thorough legitimacy to negotiate over the rights of a class ${ }^{68}$. Thus, the judge must attest, in the particular case, to the conditions of the plaintiff of the class action to represent the interests of the group in the capacity of Named Plaintiff.

In Brazil, for filing a class action or for offering the undertaking of adjustment of conduct, both in and out of court, we have it that different institutions have the appropriate standing.This standing is concurrent through the plurality of parties

point on the range [discounted to present value]. KLONOFF, Robert. Class Actions and Other Multi-Party Litigation in a Nutshell. West Academic, 2017. Kindle's edition.

${ }^{66}$ PINHO, Humberto Dalla Bernardina de. O Marco Legal da Mediação no Brasil: Comentários à Lei n 13.140/15.1 ed. São Paulo: Atlas, 2015, p. 17.

${ }^{67} \mathrm{GIDI}$, Antonio. Class action in Brazil - a model for civil law countries. The American Journal of Comparative Law, v. 51, n. 2, 2003, p. 26.

${ }^{68}$ FISS, O.M. Against Settlement, 93 Yale Law Journal 1073-90, May 1984, p.1,444. 
legitimate to bring the action or to offer the settlement, besides being disjunctive since there is no need for one legitimate party having the consent of the others to act.

Even though concurrent and disjunctive legitimization is potentially a factor that may compromise the degree to which the undertaking is definitive, this configuration is important to encompass all the possibilities of defense of the rights of the collectivity, considering that the legal situations over collective rights may establish among them a markedly-conflicting relationship ${ }^{69}$.

Some measures may also be adopted to strengthen the stability of the agreement. For example, there must be a prior attempt to notify the greatest possible number of interested parties, to allow them to attend a public hearing before the procedure is brought to a close. It is also possible to seek the participation of others enjoying legitimacy and bodies and entities to act as a friend of the court. Hearing others with legitimacy proves to be important to avoid the filing of possible later lawsuits on the same matter, due to dissatisfaction with the undertaking signed, generating the endless discussions on pending suits and res judicata that we see today.

The remarks set out lead us to the following query: would the mechanism of the Class Action Settlement, created in a country eminently liberal which, to bind the absent members, with no opportunity to speak up, considers court ratification necessary be with or against the flow of the Brazilian collective consensual system that was projected?

On this point, always timely are the teachings of Jose Carlos Barbosa Moreira on the risks on uncritically importing foreign techniques, without taking into account the structural aspects of each legal system ${ }^{70}$.

It seems to us that, aside from the distinctions between the two systems in relation to legitimization, res judicata and the sophisticated and watchful system of suitable representativeness, the understanding that court ratification would be necessary to attribute effectiveness to agreements made by private institutions, when it involves negotiable-unavailable rights, would be an interesting mechanism in order to avoid non effective settlements or even agreements unsuitable to all class members.

\footnotetext{
${ }^{69}$ MANCUSO, Rodolfo de Camargo. Interesses difusos: conceito e legitimação para agir. $6^{\mathrm{a}}$ Ed. São Paulo: Ed. RT, 2004, p. 94.

${ }^{70}$ BARBOSA MOREIRA. O processo norte-americano e a sua influência, Parte Geral, Especial e a influência do processo penal norte-americano. In: Temas de Direito Processual, $8^{\mathrm{a}}$ série. São Paulo, Saraiva, 2004, p. 223.
} 


\section{Closing remarks}

As part of a worldwide movement towards stimulating suitable mechanisms for conflict resolution, the 2015 Code of Civil Procedure and the Mediation Act bring in significant advances to the consensual system of overcoming conflicts in the collective field, as they increase the subject susceptible to negotiations, attributing greater autonomy to those legitimized to settle.

Besides the increase of these techniques, the normative innovations also raise the need for an operational systematization. How can we make use of the legal permission and apply the strategies emerged in a wide-ranging procedure of dialog, which is suited to meta-individual interests?

Firstly, mechanisms of control of these "new agreements" are indispensable. However, there is nothing to oblige this being done by the Judiciary Branch, given that court ratification is unnecessary when it is proposed by a public institution. Nevertheless, if the settlement is proposed by a private body, then the judicial scrutiny is mandatory.

But it should be noted that, in this context, the success of consensual practice in these complex conflicts must be a plural settlement of society ${ }^{71}$, not just of the bodies enjoying legitimacy, but also of the so called "amicus curiae".

Another interesting alternative, especially in the part of large-scale works which may pose threats to the environment, is the mechanism of Dispute Boards, an institute widely used in U.S. law and which is beginning to be used in Brazil. It is interesting to

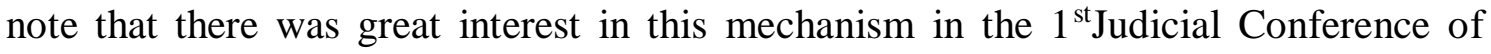
Conflict Prevention, organized by the STJ (Superior Court of Justice), under the presidency of Justice Luis Felipe Salomão, and which led to the publication of some Statements $^{72}$.

\footnotetext{
71 PINHO, Humberto Dalla Bernardina de. PAUMGARTTEN, Michele Pedrosa. Os Desafios para a Integração entre o Sistema Jurisdicional e a Mediação a Partir do Novo Código de Processo Civil. Quais as Perspectivas para a Justiça Brasileira? In: REZENDE, Diogo. PELAJO, Samantha. PANTOJA, Fernanda (org.). A Mediação no Novo Código de Processo Civil. Rio de Janeiro: Forense, 2015, p. 11.

72 On the mechanism of Dispute Boards, 3 Statements were approved in the $1^{\text {st }}$ Forum of Prevention and Out-of-Court Solution of Conflicts. We stress here Statement No. 76: Decisions rendered by a Dispute Board, when the parties contracting have agreed for its obligatory adoption, bind the parties to their observance until the competent arbitral tribunal or the Judiciary Branch issues a new decision or confirms them, if thus urged by the party not accepting the decision. Statements approved in the $1^{\text {st }}$ DAY OF "PREVENTION AND OUT-OFCOURT SOLUTION OF CONFLICTS", held in Brasilia on August 22 and 23 2016, available at: http://www.cjf.jus.br/cjf/.
} 
It is interesting to point out that Deborah Hensler" ${ }^{73}$, in her study "A Glass half full, a glass half empty: the use of alternative dispute resolution in mass injury litigation" deals in detail with appropriate methods of solution of conflicts applied to mass litigation, from two separate standpoints, making use of the proverb of water halfway up the glass. The writer's conclusions, albeit based on the context of mass conflicts under U.S. law, prove to be fully pertinent to those who hold that the glass is half full in the Brazilian collective consensual system (political-institutional legitimized parties): it is time to bring all those interested into the dialog.

In this regard, institutional behavior must be so as to make feasible an instance for swapping ideas, with space for statements from all the players, while also ensuring that the directions chosen must also take into consideration all the interests legitimately exposed. The need for structuring measures to put into effect the obligation agreed on makes this wide-ranging participation even more important. If correctly coordinated, these measures may be a suitable means for promoting public policies to put into practice fundamental rights unsatisfactorily met.

Our society has already achieved a minimal organizational level so as to afford the social fabric necessary to have fundamental matters managed, if participation is thrown open to those interested and to third parties who may assist the legitimized party in taking the best decision for the case, thus avoiding, particularly, a movement which, however well-intentioned, entails undesirable consequences.

This is the challenge facing law operators in this scenario of Brazilian legislative evolution: to align material and procedural covenants, unavailable rights, yet negotiable, and to ensure the creation of a locus suitable for dialog and which identifies a consensual measure, when possible, and one of imposition in other cases, while always ensuring all those interested of the right to a voice.

\section{References}

1. ALMEIDA, Diogo Assumpção Rezende de. Das Convenções Processuais no Processo Civil. Tese de Doutoramento. Universidade do Estado do Rio de Janeiro - UERJ, Rio de Janeiro, 2014.

\footnotetext{
${ }^{73}$ HENSLER, Deborah R. A Glass half full, a glass half empty: the use of alternative dispute resolution in mass personal injury litigation. In: 73 Texas Law Review 1587, June 1995, p. 20.
} 
2. ALMON, Matthew. Cadillac-Size Legal Fees" and "Chevrolet-Type Results": Settlement Scrutiny in Re Electronic Data Systems Corp. "Erisa" Litigation, 80 Tul. L. Rev. 2007. Accesso through Westlaw. 22nd Jan 2018.

3. BARBOSA MOREIRA, José Carlos. Convenção das partes sobre matéria processual. In: Temas de Direito Processual. $3^{\text {a }}$ série. São Paulo: Saraiva, 1984.

4. BARBOSA MOREIRA. O processo norte-americano e a sua influência, Parte Geral, Especial e a influência do processo penal norte-americano. In: Temas de Direito Processual, 8a série. São Paulo, Saraiva, 2004.

5. BEDAQUE, José Roberto dos Santos. Tutela cautelar e tutela antecipada: tutelas sumárias e de urgência (tentativa de sistematização). 4. ed. São Paulo: Malheiros, 2006.

6. CARVAlHO FILHO, José dos Santos. Ação Civil Pública: Comentários por Artigo. $3^{\text {a }}$ Ed., Rio de Janeiro: Lumen Juris, 2001.

7. CUNHA, Leonardo Carneiro. Negócios Jurídicos Processuais no Direito Brasileiro. Disponível na internet. https://www.academia.edu/10270224. Acesso em 17 de abril de 2015.

8. DIDIER JR, Fredie. BOMFIM, Daniela. Colaboração premiada (Lei n. 12.850/2013): natureza jurídica e controle da validade por demanda autônoma um diálogo com o Direito Processual Civil, https://www.academia.edu/25608182/Colabora\%C3\%A7\%C3\%A3o_premiada_ Lei_n._12.850_2013_natureza_jur\%C3\%ADdica_e_controle_da_validade_por_ demanda_aut\%C3\%B4noma_um_di\%C3\%A1logo_com_o_Direito_Processual_ Civil, acesso em 10 de julho de 2016.

9. DOLE Jr., Richard F. The Settlement of Class Actions for Damages. 71 Colum. L. Rev. 971.

10. EISENBERT, Theodore. MILLER, Geoffrey P. Attorney Fees in Class Action Settlements: An Empirical Study. Journal of Empirical Legal Studies Volume 1, Issue 1, 27-78, March 2004. Electronic copy available at: htttp://scholarship.law.cornell.edu/facpub/356/, access in November 2017.

11. ERICHSON, Howard M. The Problem of Settlement Class Action. 82 Geo. Wash. L. Rev. 951. Access through Westlaw in Jan $9^{\text {th }} 2018$.

12. FISS, O.M. Against Settlement, 93 Yale Law Journal 1073-90, May 1984.

13. FISS, O.M. The Class Action Rule, 78 Notre Dame Law Review, 1419 (2003).

14. FISS, O.M. The political theory of the class action. Washington and Lee Law Review vol. 53 (1996).

15. FITZPATRICK, Brian T. An Empirical Study of Class Action Settlements and Their Fee Awards. 7 Journal of Empirical Legal Studies (forthcoming 2010). Electronic copy available at: http://ssrn.com/abstract=1442108, access in November 2017, p. 9.

16. GIDI, Antonio. A Class Action como instrumento de tutela coletiva de direitos. São Paulo: Revista dos Tribunais, 2007.

17. GIDI, Antonio. Class action in Brazil - a model for civil law countries. The American Journal of Comparative Law, v. 51, n. 2, 2003. 
18. GRECO, Leonardo. Instituições de Processo Civil - Introdução ao Direito Processual Civil. vol. 1, 5 ${ }^{\text {a }}$ ed, Rio de Janeiro: Forense, 2015.

19. GRECO, Leonardo. O juiz pode ser sujeito de um negócio processual?Palestra proferida no Seminário "Negócios Processuais no Novo CPC" promovida pela Associação dos Advogados de São Paulo/SP - AASP, em 06 de março de 2015.

20. HENSLER, Deborah R. A Glass half full, a glass half empty: the use of alternative dispute resolution in mass personal injury litigation. In: 73 Texas Law Review 1587, June 1995.

21. KLONOFF, Robert. Class Actions and Other Multi-Party Litigation in a Nutshell. West Academic, 2017. Kindle's edition.

22. MACÊDO, Lucas Buril de; PEIXOTO, Ravi de Medeiros. Negócio processual acerca da distribuição do ônus da prova. Revista de Processo, vol. 241/2015, p. 463-487, mar/2015.

23. MACEY, Jonathan R. MILLER, Geoffrey P. Judicial Review of Class Action Settlements, 1 J. Legal Analysis 167. Access through Westlaw. Jan 8th 2018.

24. MANCUSO, Rodolfo de Camargo. Interesses difusos: conceito e legitimação

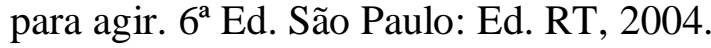

25. MARTEL, Letícia de Campos Velho. Direitos fundamentais indisponíveis: limites e padrões do consentimento para a autolimitação do direito à vida. Tese de Doutorado. Uerj, 2010. Disponível em: http://works.bepress.com/leticia_martel/.

26. NERY JR., Nelson. O compromisso de ajustamento de conduta como transação hibrida e a problemática teorização da passagem do exercício do poder público para tentativa de ajuste no âmbito privado. In: A Ação Civil Pública após 25 anos. MILARÉ, Édis (coord.), São Paulo: Revista dos Tribunais, 2010.

27. NERY, Ana Luiza de Andrade. Compromisso de Ajustamento de Conduta. Teoria e Análise de casos práticos. $2^{\mathrm{a}}$ Ed. São Paulo: Revista dos Tribunais, 2012.

28. OQUENDO, Angel. State Settlements in Vindication of Societal Rights. Original paper kindly provided by the author in January 2018.

29. PINHO, Humberto Dalla Bernardina de; FARIAS, Bianca Oliveira de. Apontamentos sobre o compromisso de ajustamento de conduta na Lei de Improbidade Administrativa e no Projeto de Lei da Ação Civil Pública. In: Temas de Improbidade Administrativa. $1^{\text {st }}$ edition, Rio de Janeiro: Lumen Juris, 2010, v.1.

30. PINHO, Humberto Dalla Bernardina de. O Marco Legal da Mediação no Brasil: Comentários à Lei n 13.140/15.1 ed. São Paulo: Atlas, 2015.

31. PINHO, Humberto Dalla Bernardina de. PAUMGARTTEN, Michele Pedrosa. Os Desafios para a Integração entre o Sistema Jurisdicional e a Mediação a Partir do Novo Código de Processo Civil. Quais as Perspectivas para a Justiça Brasileira? In: REZENDE, Diogo. PELAJO, Samantha. PANTOJA, Fernanda (org.). A Mediação no Novo Código de Processo Civil. Rio de Janeiro: Forense, 2015. 
32. PINHO, Humberto Dalla Bernardina de. The Undertaking of Adjustment of Conduct in Brazilian Collective Procedural Law. Connecticut Journal of International Law. Vol, 27: 346, Spring 2012.

33. PINHO. Humberto Dalla Bernardina de. MELLO PORTO, José Roberto Sotero de. Colaboração premiada: um negócio jurídico processual? In Revista Magister de Direito Penal e Processual Penal, vol. 73, Ago/Set 2016, Magister: Porto Alegre.

34. PIZZOL, Patrícia Miranda. Liquidação nas ações coletivas. São Paulo: Lejus, 1998.

35. RATNER, Morris A. Class Conflicts, 92 Wash. L. Rev. 785. Access through Westlaw. Jan 6th 2018.

36. ROQUE, Andre Vasconcelos. Class actions - ações coletivas nos Estados Unidos: o que podemos aprender com eles? Salvador: Juspodivm, 2013.

37. RUBENSTEIN, William B. Emerging Issues in Class Action Law. 53 UCLA L. Rev. 1435. Access through Westlaw.Jan, 18th, 2018.

38. SALLES, Carlos Alberto de. Arbitragem em Contratos Administrativos. Rio de Janeiro: Forense, 2012.

39. SMITH, Thomas. WILLIAMS Elizabeth. Court approval of class action settlement, 6 Cyc. of Federal Proc. $\S 23: 42$ (3d ed.). Access through Westlaw. Jan $5^{\text {th }}, 2018$.

40. TAKAHASHI, Bruno. Desequilíbrio de poder e conciliação, Brasília: Gazeta Jurídica, 2016.

41. TARTUCE, Fernanda. Igualdade e Vulnerabilidade no Processo Civil. São Paulo: Método, 2012.

42. VENTURI, Elton. Transação de Direitos Indisponíveis? In Revista de Processo, vol. 251, São Paulo: Revista dos Tribunais, jan / 2016.

Recebido em: 08/02/2018

Aceito em: 10/03/2018 